\title{
Studies on the lytic enzyme from Streptococcus mutans VI The correlation between the lytic ability and bacteriocin activity against Streptococcus sanguis, and artificial plaque forming ability of oral bacteria Streptococcus mutans
}

\author{
Hisae Baba and Keiko Kanamori \\ Department of Oral Microbiology, School of Dentistry, Higashi Nippon \\ Gakuen University, Tobetsu, Ishikarigun, Hokkaido, Japan 061-02
}

[Accepted for publication: June 20, 1985]

\begin{abstract}
Key words: lytic ability/bacteriocin activity/artificial plaque forming ability/Streptococcus mutans / Streptococcus sanguis

Abstract : Lytic ability and bacteriocin activity against Streptococcus $(S$.) sanguis ATCC 10556, 10557 and 10558 and artificial plaque forming ability by 119 strains of $S$. mutans were examined. Previously we have shown that 104 strains were serotype c/e/f and 15 were $\mathrm{d} / \mathrm{g}$.

Serotype c/e/f strains showed a fairly good lytic ability against $S$. sanguis ATCC 10558, but not against ATCC 10556 and 10557. They showed a higher bacteriocin activity against $S$. sanguis ATCC 10556 and 10557 than against ATCC 10558. In serotype d/g strains, a slight lytic ability against $S$. sanguis ATCC 10558 but not two others was seen, and an extremely slight bacteriocin activity against all $S$. sanguis strains was noted. The artificial plaque forming ability by $\mathrm{d} / \mathrm{g}$ type strains was clearly higher than $\mathrm{c} / \mathrm{e} / \mathrm{f}$ type strains. These facts seem to show that these factors from $S$. mutans compensate for the defects of each other. From these results, it is probable that not only bacteriocin activity, but the lytic ability and artificial plaque forming ability of $S$. mutans also take part in the decrease of $S$. sanguis in the dental plaque.
\end{abstract}

\section{Introduction}

In the dental plaque on sound tooth surface, Streptococcus $(S$.) sanguis is predominant in the streptococcal flora, but in the dental plaque on the tooth where the onset of dental caries is seen, or in the presence of a carious lesion, $S$. mutans shows a marked increase while $S$. sanguis decreases ${ }^{1-8)}$. As antagonistic agents from $S$. mutans against $S$. sanguis, bacteriocin or bacteriocin-like substances are known ${ }^{9-12}$. We have reported that $S$. mutans strains freshly isolated from the dental plaque of an infant lysed heated cells of $S$. sanguis ATCC 10558 strain $^{8)}$.

The present report describes the correlation between the lytic ability and bacteriocin activity against $S$. sanguis strains, and the artificial plaque forming ability of $S$. mutans strains isolated from the dental plaques of infants.

\section{Materials and Methods}

\section{Organisms}

S. sanguis ATCC 10556 (serotype : I), 10557 (serotype : II ) and 10558 (serotype : III) strains were kindly donated by Prof. K. Kaneko, Iwate Medical University, Iwate, Japan. One hundred and nineteen strains of $S$. mutans (Table 1) were freshly isolated from the dental plaques of 20 Japanese infants ${ }^{17}$.

Lytic ability assay

Stab culture method was used for the measurement of the lytic abilities of $S$. mutans against $S$. sanguis. Cells of $48 \mathrm{hr}$-culture on Mitis-Salivarius agar (MS agar, Difco) 
plates were stab inoculated TSL agar plate $^{17)}$ containing heat-killed cells of $S$. sanguis, and incubated at $37{ }^{\circ} \mathrm{C}$ for 5 days at an atmosphere of $95 \%$ nitrogen and $5 \%$ carbon dioxide. The TSL agar plate consisted of $\mathrm{Tr}$ ypticase soy broth (BBL): $21 \mathrm{~g}$, Heart infusion broth (Difco): $3 \mathrm{~g}$, yeast extract (Difco) $: 3 \mathrm{~g}$, L-cysteine $\cdot \mathrm{HCl}: 0.3 \mathrm{~g}$, sodium thioglycollate: $0.3 \mathrm{~g}$, hemin : $5 \mathrm{mg}$, menadione : $0.5 \mathrm{mg}, \quad \mathrm{K}_{2} \mathrm{HPO}_{4}: 2.5 \mathrm{~g}$, agar : 17 $\mathrm{g}$, deionized water : $1,000 \mathrm{ml}$, and heat-killed cells of $S$. sanguis strains : 10-15 g (wet weight), and was adjusted to $\mathrm{pH} 7.3$.

Lytic abilities were determined by the widths of the lytic zones formed around the col. onies of stab strains.

\section{Bacteriocin activity assay}

In a modification of the methods of Weerkamp et al. ${ }^{11}$, cells of $48 \mathrm{hr}$-culture on MS agar plates were stab inoculated into Trypticase soy agar plate containing $0.5 \%$ yeast extract (TS-Y agar plate), and incubated at 37 ${ }^{\circ} \mathrm{C}$ for $48 \mathrm{hr}$ anaerobically. The plates were then exposed to chloroform vapor $30 \mathrm{~min}$ and aired. After this, over-night cultures of indicator strain, diluted ten-fold into TS soft agar $(0.5 \%$ agar $)$, were sprayed over the plates, which were incubated for another $24 \mathrm{hr}$.

Bacteriocin activities were measured by the widths of clear inhibition zones appearing around the colonies of producer strains.

\section{Artificial plaque forming ability}

A modification of the methods of Fitzgerald et al. ${ }^{18)}$ was used as the test system. Sun cobalt clasp wires (diameter : $1.2 \mathrm{~mm}$, Sankin Industry Co., Ltd) were inserted in rubber stoppers and suspended in tubes containing $0.2 \mathrm{~m} l$ of an over-night culture of the test organism and $10 \mathrm{ml}$ of the TYS medium, and incubated at $37^{\circ} \mathrm{C}$ for $24 \mathrm{hr}$ anaerobically. The TYS medium composed of Trypticase peptone (BBL): $17 \mathrm{~g}$, yeast extract: $5 \mathrm{~g}$, $\mathrm{K}_{2} \mathrm{HPO}_{4}: 5 \mathrm{~g}$, sucrose : $100 \mathrm{~g}$ and deionized water : $1,000 \mathrm{ml}$, and was adjusted to $\mathrm{pH}$ 7.3.

Each day a tube of fresh medium $(10 \mathrm{~m} l)$ was incubated with $0.2 \mathrm{ml}$ of an over-night culture of the test organisms and the wires were transferred to it. After 8 days, the artificial plaques on the wires were dried

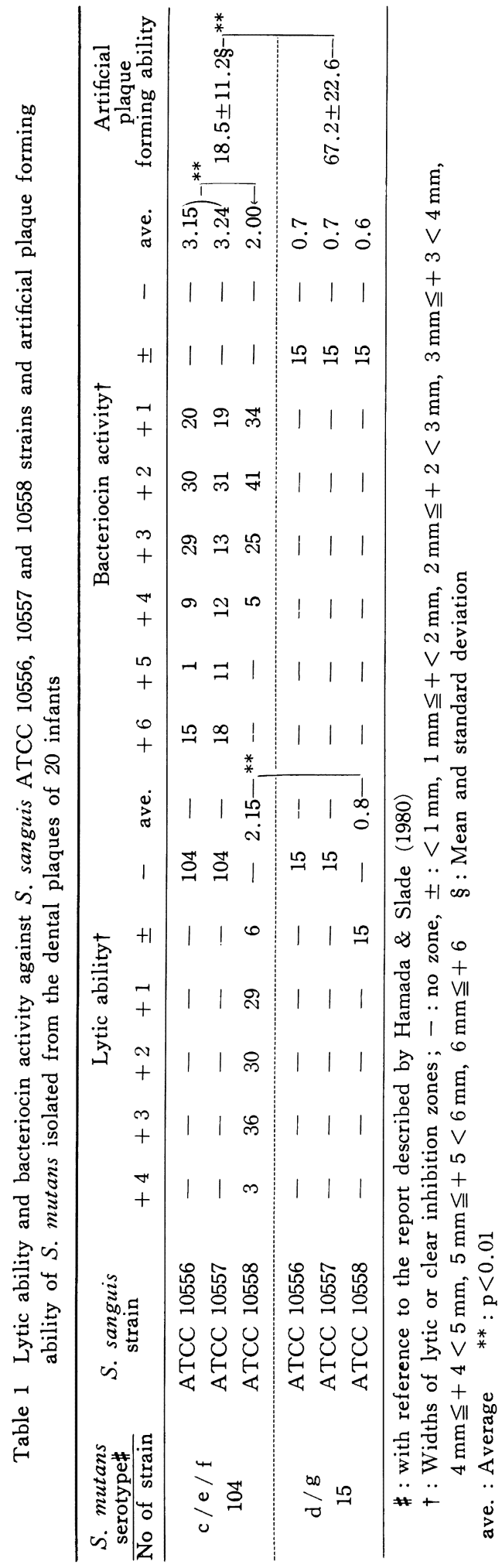


and the weight were determined.

\section{Results and Discussion}

In Table 1, lytic ability and bacteriocin activity against $S$. sanguis ATCC 10556, 10557 and 10558 strains, and artificial plaque forming ability of 119 strains of $S$. mutans isolated from 20 infants were summarized. Previously we have shown that 104 strains from 19 infants were serotype c/e/f group and 15 strains from one infant were $\mathrm{d} / \mathrm{g}$ with reference to the report described by Hamada $\&$ Slade $^{19)}$ on the basis of their biological characteristics $^{17)}$.

Based on the biotype, $S$. sanguis ATCC 10556 strain is similar to ATCC 10558 strain $^{20)}$. But on the DNA base sequence, AT. CC 10556 strain belongs to genetic group 3, while ATCC 10558 strain belongs to group $1^{21)}$. Rosan ${ }^{22-24)}$ showed that ATCC 10558 strain had $a$ and $b$ antigens in the cell walls, but ATCC 10556 strain had only a antigen on the immunoelectrophoretic test. Moreover, it was reported that $S$. sanguis ATCC 10557 strain did not possess lipoteichoic acids in the cell walls while ATCC 10556 strain $\mathrm{did}^{25)}$. Thus, the structural materials of cell walls differed among these three strains. This seems to be because only $S$. sanguis ATCC 10558 strain was lysed by $S$. mutans strains, but the other two ATCC strains were not sensitive to them. Furthermore, a large difference between serotype $\mathrm{c} / \mathrm{e} / \mathrm{f}$ and $\mathrm{d} / \mathrm{g}$ groups was observed in lysis of $S$. sanguis ATCC 10558 strain by $S$. mutans strains (p $<0.01$ ).

On the other hand, it is described that bacteriocins (or mutacins) produced from $S$. mutans are present in molecular weight from low M.W. : 1,000 to 3,500$)^{12}$ to high (M. W. : 973,00$)^{26)}$, and hinder the growth of numerous gram positive organisms including $S$. sanguis ${ }^{9-12}$. In this experiment using the stab culture method, all 119 strains of $S$. mutans showed bacteriocin activities against three ATCC strains of $S$. sanguis (Table 1). However, the activities of serotype c/e/f strains were stronger than those of serotype $\mathrm{d} / \mathrm{g}$ strains. And serotype c/e/f strains showed stronger bacteriocin activities against $S$. sanguis ATCC 10556 and 10557 strains which were not lysed by all $S$. mutans strains, but weaker activities against ATCC 10558 strain which was fairly lysed $(p<0.01)$.

Since dental plaque contains large quantities of microorganisms, their accumulation results in the lowering of oxidation-reduction potential by the growth of oxygen dependent organisms and lowering of $\mathrm{pH}$ by the growth of acidogenic bacteria. It is suggested that these lowerings of oxidation-reduction potential ${ }^{13,14)}$ and of $\mathrm{pH}^{15,16)}$ are favorable to growth of $S$. mutans in opposition to the reduction of metabolic activities of $S$. sanguis. In this study, the artificial plaque forming ability of $S$. mutans was clearly higher in serotype $\mathrm{d} / \mathrm{g}$ strains with showed very weak lytic ability and bacteriocin activity, than in serotype $\mathrm{c} / \mathrm{e} / \mathrm{f}$ strains $(\mathrm{p}<0.01)$.

These results seem to show that the main inhibiting factors of serotype c/e/f strains to the growth of $S$. sanguis strains are the bacteriocin activity and lytic ability, and that of serotype $\mathrm{d} / \mathrm{g}$ strains is the artificial plaque forming ability.

抄緑: Streptococcus ( $S$.) mutans の S. sanguis に対する溶菌作用活性, bacteriocin 活性および人 工歯垢形成能を測定し，これらの因子間の関連性について検討した。S. mutans は20名の幼児の歯垢か ら分離した104株（serotype c/e/f：104株と d/g：15株）を用いた。c/e/f 型の S. mutans は, S. sanguis ATCC 10558 株に対して良好な溶菌作用を示したが，ATCC 10556 株と 10557 株に対してはまっ たく溶菌作用を示さなかった。また，これらの S. mutans 株は，S. sanguis ATCC 10556と10557の 2 株に対して良好な bacteriocin 活性を示したが，ATCC 10558 株に対しては比較的弱い活性を示した。 また, S. mutans の菌株の違いによってもその強さは異なった。

一方, d/g 型の $S$. mutans は S. sanguis ATCC 10558株に対してのみ, 弱い溶菌活性を示し, さら に bacteriocin 活性もいうれの $S$. sanguis 株に対しても非常に弱い活性しか示さなかった。しかしな がら，人工歯垢形成能は， c/e/f 型の菌株に比べて明らかに高い形成能を示した。これらのことからこ 
れらの 3 因子は S. sanguis の增殖の抑制といら点で互いに相補的関係を示す傾向があることがわかった。

以上の結果から，生体中においてもS. mutans が $S$. sanguis に対して溶菌作用を示すものとすれば, 溶菌作用や人工歯垢形成能もまた，bacteriocin 活性とともに歯垢中の S. sanguis の減少に少なからず 関与する可能性があることが示唆された。

\section{References}

1) Carlsson, J. : Zooglea-forming streptococci, resembling Streptococcus sanguis, Isolated from dental plaque in man. Odont. Revy, 16 : 348-359, 1965.

2) Carlsson, J.: Presence of various types of non-haemolytic streptococci in dental plaque and in other sites of the oral cavity in man. Odont. Revy, 18 : 55-88, 1967.

3) deStoppelaar, J. D., var Houte, J. and Dirks, O. B.: The relationship between Extracellular Polysaccharide-producing Streptococci and Smooth Surface Caries in 13 yearold Children. Caries Res., 3 : 190-199, 1969.

4) Littleton, N. W., Kakehashi, S. and Fitzgerald, R. : Recovery of specific "caries inducing" streptococci from caries lesions in the teeth of children. Arch. Oral Biol., 15 : 461-463, 1970.

5) Shlklair, I. L., Keene, H. J. and Simoson, L. G. : Distribution and frequency of Streptococcus mutans in caries active individuals. J. Dent. Res., 51 : 882, 1972.

6) Loesche, W. J., Walenga, A. and Loos, P.: Recovery of Streptococcus mutans and Streptococcus sanguis from a dental explorer after clinical examination of single human teeth. Arch. Oral Biol., 18 : 575, 1973.

7) Jo, E., Tomita, T., Baba, H., Yuge, A. and Ohmagari, Y.: Relation between an initiation of dental caries and a change of streptococcal flora in the denaque of infants (in Japanese). Jpn. J. Oral Biol., $19: 370$, 1977.

8) Baba, H. and Igarashi, S. : Studies on lytic enzyme from Streptococcus mutans I Isolation and characteristics of lytic bacteria against Streptococcus sanguis. Jpn. J. Oral Biol., 25 : 932-946, 1983.

9) Hamada, S. and Ooshima, T.: Production and properties of bacteriocins (mutacins) from Streptococcus mutans. Arch. Oral Biol., 20 : 641-648, 1975.

10) Dajani, A. S., Tom, M.C. and Law, D. J. : Viridins, Bacteriocins of Alphahaemoitic streptococci : Isolation, characterization and partial purification. Antimicrob. Agents and Chemother, 9 : 81-88, 1976.

11) Weerkamp, A., Bongaerts-Larik, L. and Vogels, G. D.: Bacteriocins as factors in the in vitro infection between oral streptococci in plaque. Infect. Immun. 16 : 773-780, 1977.

12) Ono, K., Kishimoto, E. and Morioka, T. : Bacterinogenicity and adhesive ability in Streptococcus mutans. (in Japanese) Jpn. J. Dent. Health., 34 : 151-156, 1984.

13) Yamada, T., Takahashi, S. and Abe, K. : Effect of Oxygen on Sugar Metabolism of Oral Streptococci. J. Dent Res., 62 : 472, 1983.

14) Yamada, T., Takahashi-Abbe, S. and Abbe, K. : Effects of oxygen on pyruvate formatelyase in situ and sugar metabolism of Stre ptococcus mutans and Streptococcus sanguis. Infect. Immun. $47:$ 129-134, 1985.

15) Iwai, Y. and Yamada, T.: Rate-limiting steps of the glycolytic pathway in the oral bacteria Streptococcus mutans and Streptococcus sanguis and influence of acidic $\mathrm{pH}$ on the glucose metabolism. Arch. Oral Biol., 25 : 163-169, 1980.

16) Harper, D. S. and Loeshe, W. E. : Growth and acid tolerance of human dental plaque bacteria. Arch. Oral Biol., 29 : 843-848, 1984.

17) Baba, H. and Igarashi, S.: Studies on lytic enzyme from Streptococcus mutans V Prevalence of bacteria lytic against heated cells of Streptococcus sanguis ATCC 10558 strain in the dental plaques of infants. Jpn. J. Oral Biol., 27 : (in press).

18) Fitzgerald, R. J., Spinell, D. M. and Stoudt, T. H. : Enzymatic removal of artificial plaques. Arch. Oral Biol., 13 : 125-128, 1968.

19) Hamada, S. and Slade, H. D. : Biology, immunology, and cariogenicity of Streptococcus mutans. Microbiol. Rev., 44:331384, 1980.

20) Facklam, R. R. : Physiological differentiation of viridans streptococci. J. Clin. Microbiol., 5 : 184-201, 1977.

21) Coykendall, A. L. and Specht, P. A. : DNA base sequence homologies among str. 
ain of Streptococcus sanguis. J. Gen. Microbiol. 91 : 92-98, 1975.

22) Rosan, B. : Antigens of Streptococcus sanguis. Infect. Immun. 7 : 205-211, 1973.

23) Rosan, B. : Relationship of the cell wall composition of group $\mathrm{H}$ streptococci and Streptococcus sanguis to their serological properties. Infect. Immun. 13 : 1144-1153, 1976.

24) Rosan, B., Lai, C. H. and Listgarten, M. A.: Streptococcus sanguis: A model in the application in immunochemical analysis for the in situ localization of bacteria in dental plaque. J. Dent. Res. Special Issue 55 : A 124-A 141, 1976.

25) Yamamoto, T., Mizuno, J. and Hamada, S.: Immunochemical properties of amphipathic antigen of Streptococcus sanguis. Jpn. J. Oral Biol. 24 : 152 (supplement), 1982.

26) Fukushima, H., Fukushima, S., Umemoto, T., Fukuhara, H. and Sagawa, H.: Purification and chemical analysis of a bacteriocin from the oral bacterium Streptococcus mutans RM-10. Arch. Oral Biol. 27 : 721727, 1982. 